\title{
TRANSLATOR'S INTRODUCTION
}

Alexandre Kojève's seminar on Hegel's Phänomenologie des Geistes, held from 1933-39 at the Ecole des Hautes Etudes in Paris, caught the imagination of a great many French thinkers and writers in their formative years, and as a result left an indelible mark on twentieth-century French philosophical, theoretical, and literary writing. ${ }^{1}$ Kojève made Hegel's so-called Master-Slave dialectic the engine of a revamped, existential Marxist vision of history, according to which all violence is perpetually recuperated into progress toward the End of History. As Michael S. Roth has put it, according to this Hegelian vision "history is not merely a slaughterbench, it is the birth of the Truth through the labor of the negative."2 Most postwar French thinkers that have had a significant readership in the United States-Sartre, Merleau-Ponty, Bataille, Blanchot, Lacan, Foucault, Deleuze, Derrida - struggled in various ways for large portions of their careers with the apparently allencompassing Hegelian system expounded by Kojève as well as the other major French Hegelians of the 1940s and 1950s, Jean Hyppolite and Eric Weil. These struggles have taken many forms; arguably their most significant effect lies in the widespread belief that tragically violent experience-sometimes meaningful, but more frequently gratuitous and aimless, and thus supposedly incapable of being recuperated into an alienating project-characterizes the living of an authentic human life.

Like a number of his Christian counterparts, Jean-Louis Chrétien offers an alternative to this persistent valorization 
of tragic violence, which is tragic precisely because it is understood to take place within a horizon of irredeemable death. Chrétien's work constantly appeals to traditions of thought that question the very assumption that experiences of loss, wounding, or falling short are in and of themselves necessarily tragic. ${ }^{3}$ The opening essay of Hand to Hand: Listening to the Work of Art sets forth the biblical story of Jacob's struggle with the angel, and Delacroix's painterly response to it, as emblematic of an experience of violence wherein, to use one of Chrétien's favorite rhetorical constructions, the chiasmus, the wound blesses and the benediction wounds. ${ }^{4}$ As Chrétien shows, Jacob and the nonbelieving Delacroix respond with similar joy to the provocative, unexpected presence of something greater than themselves, which comes upon them from outside: that is, they each unreservedly throw themselves 'body and soul' into intimate struggle with this presence. ${ }^{5}$ Such total commitment can result only from an undivided, fearless love of such an encountered presence. Indeed, by Chrétien's account neither Jacob nor Delacroix is divided by self-love or restrained by fear in their respective commitments to intimacy with the combative, irresistible presence that so insistently comes upon them.

Briefly investigating the difference between the struggle Chrétien describes and the Kojévian scenario, on the one hand, and the deconstructive contestation of that scenario carried out by Georges Bataille and Jacques Derrida, on the other, will allow us to place Chrétien's philosophy in relation to some relatively proximate contemporary patterns of thought. A key to the difference lies in what constitutes for each thinker the value and meaning of a life-and-death struggle. In the Kojévian account the "absolute negativity" that operates in a life-and-death encounter, where one or both participants is killed, can never lead to the desired recognition of autonomous human value that occasioned the encounter in the first place. A tragically violent struggle for prestige must therefore be interrupted and the 
absolute power to negate sublimated into servile work, which gradually transforms the natural world into a place where the recognition of human autonomy can finally take place. Kojève illustrates this circuitous route to the emergence of "autonomous Consciousness-of-self" by a dramatic retelling of Hegel's Master-Slave dialectic in which a bloody battle between two candidates seeking ratification of their humanity is joined, only to be interrupted by the death-fearing surrender of one (the Slave) to the other's (the newly emergent Master's) dominion. A period of forced labor follows, during which the Master experiences dissatisfaction at being recognized as human by someone he himself does not consider to be so, while the Slave, through his servile work, "transform[s] the World [ . . . and in so doing] transforms himself [by differentiating himself from the World of Nature] and thus creates the new objective conditions that allow him to take up again the liberatory Struggle for recognition that he had at first refused out of fear of death." ${ }^{\prime 6}$ By being forced on pain of death to work upon the material of the world to satisfy the master's desires, says Kojève, the slave himself gradually becomes a master of nature. His work liberates him from his own nature, which he had assumed in obeying the instinct for preservation and refusing to fight to the death. By becoming, through work, a master of nature, the slave liberates his own nature as initially defined by his fear of death at the hands of his opponent, and eventually reaches a point where he can free himself from the master. The force of death is absorbed by the slave's fear and thus transformed into a productive force, gradually emerging through the work of the slave's hands to negate nature and in the process build up sense and meaning that the slave will ultimately grasp in self-consciousness. "Thus it is the initially dependent, serving, and servile Consciousness that realizes and reveals in the end the ideal of the autonomous Consciousness-of-self, and that is thus its 'truth."'7 
Jacques Derrida follows Georges Bataille in objecting to the way in which the Kojévian account of the dialectical sublimation of the power of death (the famous Aufhebung) renders that power safe for reason by making it serve the emergence of autonomous self-consciousness. ${ }^{8}$ Bataille's deconstructive ("sovereign") textual strategies, says Derrida, trace instants of "sacred" experience that belie the Hegelian conviction that death can be so tidily put to work in order to make sense. Bataille's strategies unmask the fear of death that, in this account, lies behind Hegel's resort to the Aufhebung, and, by "miming" "heedless sacrifice" (the "absolute negativity" that Kojève says must be sublimated), allow the power of death in all of its sovereign meaninglessness to erupt momentarily into experience. Derrida writes:

To be indifferent to the comedy of the Aufhebung, as was Hegel, is to blind oneself to the experience of the sacred, to the heedless sacrifice of presence and meaning. Thus is sketched out a figure of experience ... displaced in phenomenology of mind, like laughter in philosophy, and which mimes through sacrifice the absolute risk of death. Through this mime it simultaneously produces the risk of absolute death, the feint through which this risk can be lived, the impossibility of reading a sense or a truth in it, and the laughter which is confused, in the simulacrum, with the opening of the sacred. ${ }^{9}$

Bataille's writing, says Derrida, mimes a death that is paradoxically constructed to be at once the most concrete and the most unknowable reality. Bataille's mimicry of "heedless sacrifice" contests Hegel's rejection of killing as "abstract negativity" by "mak[ing] the seriousness of meaning [rescued from death by the dialectic] appear as an abstraction inscribed in play."10

The story of Jacob's struggle with the angel testifies to an entirely different understanding of death, and thus of life. For Derrida and Bataille, death as a personal event is impossible to think of. ${ }^{11}$ There is no one outside me who can teach me anything fundamental about my death, or about my life; 
and every experience I conceive as analogous to the experience of my death is only a mere simulacrum of what, from the point of view of life as self-conscious self-sufficiency, is always already assumed to be a total loss. Despite their differences, both Hegelian and Bataillean / Derridean anthropology are characterized by what Chrétien calls an "obsession" with "the human project of total self-assurance and self-understanding . . . in transparency."12 Jacob, by contrast, struggles as a mortal who is relatively free of this obsession, and thus as one who lives convinced of the likelihood that something or someone outside him could fundamentally transform his life. Jacob's freedom is "rooted at each instant in listening to an other Word that," precisely because it is anterior to any project of self-understanding in transparency (for example, strategic plans for the morrow's encounter with Esau), "wounds body and soul."13 Such listening is dramatic, fully implicated in what it hears: Jacob's struggle becomes "amorous" precisely because his relationship to his own life is not primarily conceptual (dialectical or contestatory), but rather determined by his relationship to another. Within this relationship of loving exchange, the very death brought about through its violence is the occasion for new life. Describing Delacroix's depiction of Jacob disencumbered of his weapons as he wrestles, Chrétien writes,

To give up all defenses and weapons in order to enter into the fight, to confront the irresistible assailant counting on nothing more than one's own presentation, to come at him openly: such are the conditions of combats that are in truth matters of life and death, combats in which something of ours must die, and a new life enter to dwell within us. Only the disarmed can grow in strength. To take arms, to surround oneself with defenses, is already to place oneself in a position of weakness, and at the same time to refuse the salutary intimacy of close combat. What must die in us will only truly die by not allowing itself to die, by burning up every last bit of its power, without any reserve. This is what it means to die a natural death. ${ }^{14}$ 
The French in the penultimate sentence-brûlant sans réserve toute sa puissance mise à nu et à vif-echoes a typical Bataillean locution (brûler sans réserve) that is echoed in the subtitle to Derrida's essay on Bataille (un hegelianisme sans réserve). But the life-and-death combat described here by Chrétien differs significantly from the tragicomic, "sacrificial" mimicry described by Bataille. For Jacob, a life-and-death struggle can truly be characterized as an experience of life-giving "salutary intimacy" with another; for Bataille the joy in such a struggle is found only in the despairing experience of my own mortal anguish. ${ }^{15}$ The combat described by Chrétien culminates in a "communication of force" where "confrontation becomes exchange," rather than an "annihilation of the force of the other" (however joyful for the victim such annihilation could be imagined to be). ${ }^{16}$ Jacob and Delacroix each exemplify in their active self-abandonment to amorous struggle with the unexpected other the "mysterious lameness" that characterizes the human ontological constitution according to Judeo-Christian thought. ${ }^{17}$ For Jacob, the blow to the hip from the infinite breaks open his human finitude and dilates it, giving him a new name and more abundant life. Similarly Delacroix, in embracing as his own the irresistible, "dizzying possibility" described by the Biblical text, exhausts the final years of his life in the effort to meet the imperious demands of his work, effort that results in a mural painting whose "trenchant light ... shows" the dramatic source of its energy "without adorning or comparing" (6, 10). Chrétien's ekphrasis and analysis of Delacroix's Chapel of the Angels demonstrates that the painting succeeds because it embroils the viewer in the very drama out of which it was made: the painting testifies to the "burn" of a presence (xxvi) left upon the one who made it, and offers to the viewer the blessings of a similar wound. "Nihil sufficit animae, nisi ejus capacitatem excedat," "Nothing suffices for the soul but that which exceeds its capacity": 
when human embodied life responds with love to the irresistible assault of what is greater, it is, from within its very finitude, creatively enriched and expanded, rather than torn apart and destroyed. ${ }^{18}$

The claim that Delacroix's painting is successful implies a criterion of judgment by which such success is to be measured. One of the most interesting features of Chrétien's account of the positive, life-giving violence witnessed to by the story of Jacob and the angel is his often subtly stated yet robustly critical account of what a good painting, or a good poem, is and does. The centrality of a dramatic, intimate relationship with what is outside our self-understanding-another person, beautyfigures importantly here too. To understand Chrétien's evaluative account of the success of the art work, we need to understand first how he conceives of the work of art in its essence.

In his "Address" to the reader, Chrétien tells us that Hand to Hand constitutes "a dialogue with works and what they look upon," and that each work of art (visual or verbal) considered in the book is a "manual act of presence (drawing, painting, writing)" formed in response to the appeal seen and heard by the artist in the "acts of presence" made by human bodies (xxv). Chrétien assumes here, and especially in the essay "Silence in Painting," what he has shown at length in his book L'Appel et la réponse: that the call of beauty appeals to the entire body, so that we are absolutely accurate to say, with Paul Claudel, that the eye listens to and the ear sees the presence of beauty. "The call [appel]," writes Chrétien, "is anterior to the notion of sign, for it is the condition of possibility for its constitution." 19 The dynamic of call (or appeal) and response constitutes a path of continual antiphonal movement; thus we should understand Chrétien's careful ekphrastic translations of each of the individual works he discusses in Hand to Hand as necessarily taking their place within this dynamic, as does, in turn, our reading. ${ }^{20}$ 
Chrétien approaches the work as an existential phenomenon rather than a generic object in relationship to norms of representation, figuration, or abstraction, all of which are in Chrétien's view secondary to the essence of painting. (In this respect, Chrétien's approach to art shares aspects of the approaches of Maurice Merleau-Ponty, Henri Maldiney, and Michel Henry. ${ }^{21}$ Such an approach allows for qualitative distinctions between paintings in terms of whether or not a work is true to its phenomenal nature, which is to say, fashioned in accordance with rather than in opposition to the fact that it is the translation into forms of a human act of listening that in its turn gives itself to be listened to (57). Human beings make paintings in response to the "musical silence" of the world; when we look at a good painting, this silence is given to us to hear.

Why then do we not always hear this silence? Sometimes, says Chrétien, the fault lies with the painting; at other times, with the listener. Listening is never a solitary activity; to take place, two silences must meet and respond to one another. "It is with our silence that we listen to the silence in painting: two antiphonic silences, two silences that respond to one another, give one another a fresh start, and in a certain sense embrace one another" (19). A painting can be "chatty" (bavarde), as can a viewer. ${ }^{22}$ This, essentially, is the charge that Chrétien, at the end of the essay "Silence in Painting," levels against Georges Bataille's approach to painting. We appreciate here again an implicit continuity between the essays that make up Chrétien's book: the fullness of human existence is best described as a dramatic listening to what comes to us from outside our projects of self-understanding. Bataille, says Chrétien, drowns out the sound in painting with a "metaphysical thesis," arguing that Manet's work inaugurates a definitive, yet "impossible," rupture with discursivity in painting (56). Such "apophatic, acosmic" (54) arguments about an artist's impossible break with discursivity-impossible because, to be known, the break must be articulated discursively-have 
driven an entire generation or two of American academic writing about literature and art. They are anchored in the conviction that only the tragic violence of a double bindanother permutation of the obsession with self-understanding in transparency-marks advanced thinking.

Chrétien's alternative to such arguments is to show that the discursive-nondiscursive binary upon which they are based is of secondary importance (if indeed it exists at all) ${ }^{23}$ to the fact that human acts of presence are essentially responsive, always already inhabited by a presence that precedes and creates them. If we accept this demonstration, coherence requires us to respond with hospitality to the silence that calls us (163). Chrétien's judgments of paintings that respond to the phenomena of bodies that are sleeping or nude hinge upon the degree to which such works offer a view that is hospitable to whatever it is in these bodies that is secret, unmasterable, or invisible (78). Insofar as an ethical judgment is at issue here, it is one that is indexed to a determination of fact. Bad painting and bad poetry, as well as bad writing about painting and poetry, fail in similar ways to see and to listen to events (93). They deal in bodies that "do not exist," bodies that, in their total availability to spectatorship, no longer bear breath (78). They deal either in what is merely "mythological," or in what is dead (85).

For Chrétien, the primacy of the event guarantees the drama of existence. Elsewhere, Chrétien compares Jacob's "amorous contest" with the angel to prayer. ${ }^{24}$ In prayer, speech or a "manual act of presence" itself becomes an event. This is what Chrétien in L'Arche de la parole calls the "dramatique de la parole," the drama of speech. ${ }^{25}$ The "manual acts of presence" we make in response to the in-breaking (effraction) or advent of beauty are good and true acts when they are offered as acts of adoration. A true response to beauty emerges out of the very desire opened by its taking place. To pretend to speak about the event of beauty from a stance of spectatorial overview, as if one had not 
been touched by its taking place, is to deny the very gift of that desire. ${ }^{26}$ An excellent example of dramatic speech occurs in Hand to Hand when, concerning Delacroix's essentially responsive approach to the story of Jacob and the angel, Chrétien writes, "The founding events of sacred history do not cease to write and prolong themselves in new existences. . . . They never finish taking place, if we offer them this place that is our life. Why does Jacob matter, if we cannot become him? Why does his angel matter, if he no longer has the force to assault us? What does this combat matter, if it cannot take place this very night?" (8). These words do not argue from a point outside the drama they describe. Instead, they recall events that have taken place, give an imminent account of how they happened and go on happening, and issue an invitation to participate in their continued happening. ${ }^{27}$

Yet the stance of spectatorial pretense before beauty is virtually everywhere adopted in present-day Western culture. Why? In the essay "From God the Artist to Man the Creator" Chrétien shows how key decisions regarding the relationship between the work, the artist, and God occurring within the tradition of Christian Platonism have contributed decisively to the rise and subsequent dominance of the modern spectatorial overview. Despite our best efforts, Chrétien writes, "from the moment that the artistic analogy [comparing God to an artist] unfolds within thinking about the creative act and the relation of God to the world," the dissimilarity originally included in the artistic analogy between God as artist and man as artist fades, and man stands before God as a "creator," in a "relationship of connivance" rather than of praise $(120,119)$. Though he never argues a cause and effect relationship, Chrétien shows clearly that the fading of this strong sense of the dissimilarity between God and man, commonly held in both ancient Greek and non-Augustinian Christian thinking, coincides with a turn away from the Christological thinking that, in the work of such Christian Platonists as Saint 
Augustine and Saint Bonaventure, constantly recalls this dissimilarity (120). When it ceases to be a dramatic response to the presence of Jesus Christ, theological thinking, and especially analogical theological thinking, tends to develop a 'natural' anthropology, and to conceive of a God lacking in divinity.

This important essay is somber in tone, indeed at times severely pessimistic about the possibility that contemporary men and women might once again attend to the dramatic role of the human hand in human making. But the overall effect of Hand to Hand inspires hope in no small part because it exemplifies what it describes. The book demonstrates the intellectual and spiritual power of dramatic speech to sidestep the labor of the negative and to speak a 'yes' to the excess of the call over every response. Like Paul Claudel's saturating and thoroughly saturated "laudes aquae" (subject of the book's penultimate essay), Jean-Louis Chrétien's written words in Hand to Hand translate phenomenal experience and, at the same time, offer themselves as phenomena that witness to the continual transfiguration of human corporeal life by new possibilities. The ultimate source and goal of these possibilities is evident for those who "have ears," for what Chrétien says of Claudel's dramatic speech seems descriptive of his own parole, as well: "There can never be a question concerning God, nor our relation to God, nor the relation of God to us, without the Incarnation of God in Christ being present as at once both the center and the horizon of this word" (143). Chrétien's word tells us that, in the loving encounter with the One who exceeds us, every defeat can become a victory because the human being has been given the ability to speak from and within the memory of the event of Jesus Christ.

STEPHEN E. LEWIS

The Lumen Christi Institute, Chicago

January 2003 


\section{NOTES}

1. Vincent Descombes offers an excellent account of the influence of Kojève's interpretation of Hegel's Phenomenology on subsequent French philosophy in his book Modern French Philosophy, 9-54, 112-14, 137-41, 158-61; see also Descombes' essay "La crise française des lumières," in Philosophie par gros temps, 69-95.

2. Roth, Knowing and History, 197. Among those who attended the seminar were Raymond Aron, Georges Bataille, André Breton, Henry Corbin, Gaston Fessard, Jacques Lacan, Maurice MerleauPonty, Raymond Queneau, and Eric Weil. Kojève's teachings were assembled into book form by Queneau and published after the war: see Kojève, Introduction à la lecture de Hegel.

3. Chrétien, "Retrospection," 126. Chrétien makes an explicit comment on Kojève's interpretation of Hegel in a critique of Maurice Blanchot's appropriation and curious development of the Kojévian interpretation of naming as murder; see Chrétien, $L$ 'Arche de la parole, 6-9. Elsewhere in his millennial "Retrospection" Chrétien describes his attempts "to show that certain themes that contemporary thought has sometimes believed itself to initiate are in fact already present and alive in the ancient traditions" (125). Hand to Hand: Listening to the Work of Art employs the ancient sources-primarily Platonic-as well as the Biblical, patristic, and seventeenth-century French Catholic mystical sources found often in Chrétien's earlier as well as subsequent work; but also present in Hand to Hand are many modern, especially poetic and artistic, sources. Similar convictions about the usefulness of ancient thought in approaching contemporary problems animate Catherine Pickstock's work in After Writing, Part I of which argues against a perceived postmodern projection of modern tragic violence onto Platonic thought. Jean-Luc Marion has worked in a similar spirit, making extensive use of the Biblical distinction between idols and icons to intervene at numerous points in contemporary discussions about God, ontotheology, and givenness (cf. Marion, The Idol and Distance, God Without Being, Being Given, and In Excess). Also in Marion (although not an appeal to ancient thought) we find a particularly vivid, nontragic alternative to the Kojévian struggle scenario: love is described as a "crossing of gazes," which "imitates the crossing of swords-what [the lovers] each see of the other consists in the balanced tension of aims, like two weapons crossed" (see Marion, Prolegomena to Charity, 89). 
4. Chrétien, "Retrospection," 122.

5. A French expression to describe such unrestrained struggle is "à corps perdu," one of many expressions in the French language that uses the word "corps" when English would employ some other or additional word. The French title of this bookCorps à corps: à l'écoute de l'euvre d'art-contains another such expression. "Corps à corps," which literally means "body to body," is used in French (as in Italian and Spanish) to describe what in English is called "hand-to-hand" fighting-thus in French Chrétien describes Jacob's wrestling with the angel as "une lutte corps à corps." The emphasis on the hand in the idiom of the English title for this book (which was approved by the author) certainly mutes the original French title's emphasis on the role of the entire body as site of response to the call; yet, perhaps felicitously, the English idiom calls attention to Chrétien's beautiful description of the grappling hands in Delacroix's "Jacob and the Angel" that concludes the first essay, as well as the author's emphasis on the importance of the hand found in the final pages of the important essay "From God the Artist to Man the Creator."

6. Kojève, Introduction, 34, my translation. All translations are my own unless otherwise indicated.

7. Ibid.

8. Derrida's thought has of course developed in many ways since the 1967 publication of Writing and Difference (the book that contains Derrida's principal essay on Bataille). Yet Derrida's recent work contains patterns of thought that very much resemble those present in the 1967 book. For instance, his critical discussion in Donner la mort of the demonic, its supposed two-stage disciplinary "refoulement" or "sacrifice" in Platonism and Christianity, and the subsequent emergence of European responsibility bears striking structural similarities to his valorization of Bataille's critical engagement with the Hegelian dialectic (Derrida, Donner la mort, note in particular 24 and 29 for the emergence of Hegelian language despite the focus on Patocka's Heideggerianism).

9. Derrida, "De l'économie," 378; tran. Bass, Writing and Difference, 256 [translation slightly modified].

10. Derrida, "De l'économie," 377; tran. Bass, Writing and Difference, 256. 
11. As an example, see the passage from Bataille's Méthode de méditation, quoted by Derrida, "De l'économie," 406; tran. Bass, Writing and Difference, 276. Chrétien shows elsewhere that philosophical claims about the impossibility of thinking about death tend to result from a refusal to think seriously about immortality, and thus of death as a power belonging to the human being. Following Saint Augustine, Chrétien shows that this important feature of human agency-the power to die and the power not to die-can only be thought about coherently, in all of its valences, if mortality and immortality are understood in relation to one another. See Chrétien's essay "Pouvoir mourir et devoir mourir selon la théologie chrétienne," 165-204. I refer here most immediately to 168 , but the entire essay is pertinent. The power to die or not to die seems an obscured yet fundamental question in Bataille's thought; the precise meaning and status of suicide, in particular, is unclear in relation to the practice of certain contestatory acts that, as Derrida puts it, "mime" "sacrifice." See Ernst, Georges Bataille, 25-27, 94-104 for an enlightening discussion of the questionable status and meaning of suicide in Bataille's work.

12. Chrétien, "Retrospection," 123.

13. Chrétien, "Retrospection," 125.

14. Jean-Louis Chrétien, Corps à corps: à l'écoute de l'œuvre d'art (Hand to Hand: Listening to the Work of Art) (Paris: Les Editions de Minuit, 1997), 14-15. Further citations to the translated text will be given parenthetically in the Introduction.

15. "Gaiety, connected with the work of death, causes me anguish, is accentuated by my anguish, and in return exacerbates that anguish: ultimately, gay anguish, anguished gaiety cause me, in a feverish chill, 'absolute dismemberment,' where it is my joy that finally tears me apart, but where dejection would follow joy were I not torn all the way to the end, immeasurably." Bataille, CEuvres complètes, XII:342; translated into English as "Hegel, Death and Sacrifice," 25; quoted by Derrida, "De l'économie," 380; tran. Bass, Writing and Difference, 259.

16. Chrétien, Hand to Hand, 4. For Bataille, true sacrifice is "un sacrifice où tout est victime," in which "le sacrificateur lui-même est touché par le coup qu'il frappe, il succombe et se perd avec sa victime" (a sacrifice in which everything is a victim ... the sacrificer himself is hit by the same blow that he strikes, he succumbs and is lost with his victim). Bataille, L'expérience intérieure in OEuvres complètes, V:175, 176. 
17. Lubac, Le mystère du surnaturel, 149; tran. Sheed, The Mystery of the Supernatural, 113-14.

18. Saint Bonaventure, Quaestiones disputatae de scientia Christi, VI, quoted in Chrétien, Le regard de l'amour, 247.

19. Chrétien, L'Appel et la réponse, 18. For the full argument, see the book's first two essays: "L'Appel et la réponse," 15-44, and "La Voix visible," 45-56.

20. Chrétien's ekphrasis exemplifies the work of translation that he says necessarily takes place in every act of listening to the manifestation (call and appeal) of beauty. For more on Chrétien's understanding of response as translation (mentioned in Hand to Hand, 57), see L'Appel et la réponse, 58, 88-89, and Chrétien, "La traduction irréversible," 309-28. In this latter text, Chrétien writes, "Le premier dire est déjà traduction, notre écoute fait toujours déjà de nous un truchement. . . . La parole commence par traduire" (The first saying is already translation, our listening makes us always already an interpreter. . . Speech begins with translation [328]).

21. Merleau-Ponty wrote famously of painting in L'CEil et l'esprit: "It is impossible to say that here nature ends and the human being or expression begins. It is, then, silent Being that itself comes to show forth its own meaning. Herein lies the reason why the dilemma between figurative and nonfigurative art is wrongly posed; it is at once true and uncontradictory that no grape was ever what it is in the most figurative painting and that no painting, no matter how abstract, can get away from Being, that even Caravaggio's grape is the grape itself. This precession of what is upon what one sees and makes seen, of what one sees and makes seen upon what is-this is vision itself" (Merleau-Ponty, L'CEil et l'esprit, 87; tran. Smith, "Eye and Mind," 147). Similar points of view can be found in Maldiney, Regard, Parole, Espace, for example, 250 (a passage mentioned in Hand to Hand, 63), and in Henry, Voir l'invisible: Sur Kandinsky, for example, 221-24. For a critical map of the vast number of philosophical studies of painting written in France during the last twenty-five years, see Mongin, Face au scepticisme (1976-1993), 206-11. We can lengthen Mongin's list to include works by Alain Besançon and Jean-Marie Schaeffer, among others, if we extend it to 1997, the French publication date of Hand to Hand. 
22. In the essay "L'hospitalité du silence," in $L^{\prime}$ Arche de la parole, Chrétien describes "la parole du bavardage," chatty speech, as "speech that ... gives no silence at all to hear, and gives to silence nothing of the light it might have shed" (59). Chrétien writes that Hand to Hand's "Silence in Painting" "completes" this essay (57 n. 1).

23. Cf. Chrétien's suspicion that the radical nothingess limned "impossibl[y]" by the apophatic language of the late Greek philosopher Damascius, "the greatest 'deconstructor' in the history of philosophy," may "still be an all too human representation, the emptiness of our own mind transfigured into an idol" (Ibid., 94, 96).

24. Chrétien, "La prière selon Kierkegaard," 115; see also L'Arche, 127.

25. L'Arche, 123.

26. L'Arche, 131.

27. Chrétien speaks in similar fashion of Georges De La Tour's painting L'Adoration des bergers (Hand to Hand, 48), and of several painterly treatments of the sleep of the apostles at Gethsemane (66). In each of these three cases, Chrétien also appeals to seventeenth-century French mystical authors for keys to interpreting both the paintings and the phenomena to which they respond, namely, Jacob's wrestling, the silence of the verbum infans, and the retreat of the disciples into sleep, respectively. The approach of the French mystics is always dramatic, and obviously an inspiration for Chrétien's own writing. 